\title{
Prediction of Stature According to Three Head Measurements
}

\author{
Predicción de la Estatura de Acuerdo a Tres Medidas de la Cabeza
}

Agron M. Rexhepi* \& Behlul Brestovci**

REXHEPI, A. M. \& BRESTOVCI, B. Prediction of stature according to three head measurements. Int. J. Morphol., 33(3):1151-1155, 2015.

SUMMARY: Morphometry is a non-invasive method important to assess the size, proportions, and composition of the human body. Because the prediction is an important subject in almost all life sciences, the aim of this research was to find out the cephalofacial variables that may predict the body height. Three cephalofacial variables and the body height were measured on 288 adult male subjects of the Kosovo Albanian population, aged 18-35 years old. Using the procedures of regressive analysis we found that cephalofacial variables: head height, head circumferences, face height, significantly may predict body height, and in this way we derived the specific regression equation for estimation of the body height, based on these cephalofacial variables. The predicted body height, has relatively high significant correlation (0.512) with true body height, as well as paired T-test indicates significant similarity between these two variables.

KEY WORDS: Morphometry; Cephalofacial variables; Stature; Regression analysis.

\section{INTRODUCTION}

Morphology is a branch of bioscience that studies the form, structure and structural features of organisms. The most applied, non-invasive, and inexpensive measurement method of morphology is morphometry, which is important to assess the size, proportions, composition of the human body, as well as may be useful in the field of biometrics to better understanding development of human body (Guan \& Zhuang, 2011).

During embryonic development the skeletal elements developed through two different embryonic processes. While endochondral ossification gives rise to long bones, facial bones, vertebrae, and the lateral medial clavicles, the intramembranous ossification gives rise to the flat bones that comprise the cranium and medial clavicles (Ornitz \& Marie, 2002).

Except in some pathological cases or under some ecological factors when the different elements of the skeleton grow at different rates, almost always, the human body height has proportional biological relationships with other parts of the body (Jantz \& Jantz, 1999; Stinson \& Frisancho, 1978).

The great challenge for anthropologists is to observe and compare the relationship between stature and other segments of the body (Coon, 1939; Dhima, 1985; Rexhepi
\& Meka, 2008). So, many of them have tended with various methods to explore, find, and quantify the relationships between the craniofacial (cephalofacial) variables and body height. Stature reconstruction is important as it provides a forensic anthropological estimate of the height of a person in the living state; playing a vital role in the identification of individuals from their skeletal remains (Agnihotri et al., 2011; Krishan et al., 2010; Ryan \& Bidmos, 2007; Waghmare et al., 2011).

Many studies have been conducted on the estimation of stature from various body parts like hands, trunk, intact vertebral column, upper and lower limbs, individual long and short bones, foot and footprints, as well head (Agnihotri et al.; Auyeung et al., 2009; Duyar \& Pelin, 2003, 2010; Habib \& Kamal, 2010; Krishan, 2008; Ozaslan et al., 2012). According to Ozaslan et al. it is possible to estimate, respectively to predict human body height based on hand or foot measurements, he also has detected that the length measurements are more reliable than breadth measurements for predictive purposes of stature.

Even though, various studies have recorded changes in craniofacial shape that occur throughout life, as well as changes in the size of various craniofacial measurements, including head length, width, and circumference,

\footnotetext{
" Sport Center for increasing of morpho-functional abilities, Fitness \& Nutrition "Corpore Sano", Prishtina, Kosovo.

${ }^{*}$ Faculty of Special Education and Rehabilitation, University of Zagreb, Zagreb, Croatia.
} 
bizygomatic breadth, and anterior face height, the estimation of stature from craniofacial dimensions is without doubt important in forensic cases. Regarding these facts the conclusions of the scientists are different, some of them have found strong correlations between cephalofacial measurements and stature, whereas some of them have not.

Patil \& Mody (2005), in order to predict body height in males as well as females, have derived regression equations using only the measurement of maximum head length, specified as glabella-opisthocranion.

Ryan \& Bidmos found moderate correlations of up to 0.45 between an individual cranial measurement and skeletal height and up to 0.54 for combinations of cranial measurements, which were chosen using stepwise regression.

Kalia et al. (2008) has tried to predict the dimension of body height based on the dimensions of the teeth, and according to him, even though tooth dimensions alone may not be useful in prediction of body height, the skull with teeth may provide accurate predictive clues for human body height.

Rao et al. (2009) using the lengths of the coronal and sagittal sutures have attempted to derive regression equations for the estimation of body height. They found significant correlation with a coefficient of 0.363 between body height and coronal suture length in males.

Pelin et al. (2010) have measured 286 healthy, living, male Turkish subjects, and have not found any strong correlation between their cephalofacial measurements and body height. According to them cephalofacial dimensions are not good predictors for body height for the Turkish population.

According to Agnihotri et al., Asha \& Lakshmi Prabha (2011), and Krishan \& Kumar (2007) and Krishan (2008) the cephalofacial measurements are strongly and positively correlated with stature. The regression analyses showed that the cephalic measurements give better prediction of the stature than facial measurements.

Based on the results of Ilayperuma (2010) cranial dimensions provide an accurate and reliable means in estimating the height of an individual.

Because the prediction is one of the most important subjects in almost all life sciences, the aim of this research was to find out the cephalofacial variables that may predict the body height.

\section{MATERIAL AND METHOD}

The present study is a part of the project "Morphological characteristics of the Kosovo Albanian population" that was conducted at the Institute of Sports Anthropology in Prishtina, Kosovo, and received approval from the Ethics Committee of the University Clinical Center in Prishtina.

According to the International Biological Program three cephalofacial variables were measured, as well as the body height (stature). The measurements were done on 288 adult male subjects of the Kosovo Albanian population, during the period 1997-2002. The examined subjects aged $18-35$ years of age, were chosen randomly, respecting the rule that their psycho-physic, skeletal, dental and soft tissue condition were normal.

The estimation of stature from body parts involves specialized anthropometric techniques applied with great precision (Krishan \& Kumar).

Following the definitions of Martin \& Saler (1959) morphometric variables were measured by classical anthropometric instruments: anthropometer, cephalometer, metric tape, as well as with sliding compass, with accuracy of $1 \mathrm{~mm}$.

Because the body height is the most mesostabyl longitudinal dimension of the human body, this study was carried out to investigate the possibility of estimating of body height of a person based on their cephalofacial variables, by application of regression analysis.

The following morphometric variables were measured:

ST - Body height (Stature);

V-Po (vertex-porion) - head height;

HC - Head circumference;

$\mathrm{N}$-Gn (nasion-gnathion) - face height;

Statistical analysis was performed using SPSS statistical software (version 17.0)

Regression analysis is one of the most commonly used statistical techniques, with applications in almost every scientific field. Whereas canonical correlation simultaneously predicts multiple dependent variables from multiple independent variables, regression analysis predicts a single dependent (criterion) variable from a set of multiple independent (predictor) variables, respectively explores their relationships. 
Through Regression Analysis we explored the possibility of prediction of body height (stature) with three selected cephalofacial variables: head height, head circumference, and face height.

\section{RESULTS AND DISCUSSION}

Considering that our aim was to find out whether three selected cephalofacial variables significantly will predict body height, these variables were ranked as the predictor (independent) variables, whereas the body height as the criterion (dependent) variable.

Using the regression analyses we have tested whether the set of cephalofacial variables has explained a statistically significant amount of the variability ( $p<0.05$ ) of body height.

Certainly the null hypothesis of regression analysis in this study may be that three selected cephalofacial variables will not explain variability of body height, while the alternate hypothesis may be that they will explain a statistically significant amount of the variability.

According to the data of Table I the system of independent variables (head height, head circumference, and face height) significantly $(\mathrm{p}<0.000)$ predicts $26.2 \%$ of total variance of the dependent variable (body height). The Durbin-Watson test was calculated to evaluate if the autocorrelation, respectively the independence of the predictor errors (residuals) has been detected in the regression model. According to the value of this test (DW= $1.555>0.8)$ it can be concluded that the error deviations, respectively the residuals are uncorrelated, autocorrelation corrected is not needed, and thus can be continued with further statistical procedures.

From the data of Table II it can be defined that independent variables that have more influence on the dependent variable. In our study, it was found that all three selected cephalofacial variables significantly may predict the estimation of body height.

According to the data of Table II, with intention to predict the body height is derived the specific regression equation for measured population:

$$
\mathrm{Y}=?+(\mathrm{Bi} \times \mathrm{V}-\mathrm{Poi})+(\mathrm{Bi} \times \mathrm{HCi})+(\mathrm{Bi} \times \mathrm{N}-\mathrm{Gni})
$$

The prediction of body height was estimated for each measured entity based on the above linear regression equation. The value of the observed body height were compared with the gained value of the estimated body height, and was found that the difference ranges from $-5.36 \mathrm{~cm}$ to $3.69 \mathrm{~cm}$ (Table III).

The predicted body height has realized relatively high significant correlation (0.512) with true living body height (Table III), whereas differences between them were assessed using paired t-tests that indicate no significant differences between these two variables (Table IV).

Table I. Regression Model Summary.

\begin{tabular}{lcccccr}
\hline Model & R & R2 & $\begin{array}{c}\text { Adjusted } \\
\mathbf{R 2}\end{array}$ & $\begin{array}{c}\text { SE of the } \\
\text { estimate }\end{array}$ & Durbin-Watson & Sig. \\
\hline 1 & 0.512 & 0.262 & 0.254 & 41.65 & 1.555 & 0.000 \\
\hline Predictors: (Constant) & V-Po, HC, N-Gn & Dependent Variable: ST (Stature) & &
\end{tabular}

Table II. Regression Coefficients.

\begin{tabular}{lccccc}
\hline & B & SE & Beta & t & Sig. \\
\hline (Constant) & 887.119 & 96.305 & --- & 9.212 & 0.000 \\
V-Po & 1.647 & 0.389 & 0.234 & 4.235 & 0.000 \\
HC & 0.880 & 0.190 & 0.267 & 4.639 & 0.000 \\
N-Gn & 1.484 & 0.411 & 0.195 & 3.606 & 0.000 \\
\hline Dependent Variable: ST (Stature) & & & &
\end{tabular}

Table III. Descriptive Statistics and Correlation.

\begin{tabular}{cccccc}
\hline & Min. & Max. & Mean & SD & R ST \\
\hline ST & 1653.0 & 1885 & 1763.75 & 48.23 & 1 \\
Estimated-ST & 1706.6 & 1848.07 & 1764.03 & 24.70 & $0.512 *$ \\
\hline * Correlation is significant at the 0.01 level (2-tailed).
\end{tabular}




Table IV. Paired Samples Test.
\begin{tabular}{ccccc} 
& & & \\
\hline Pair 1 & ST- Estimated ST & -0.111 & df & Sig. (2-tailed) \\
\hline
\end{tabular}

\section{CONCLUSION}

The results of regression analysis indicate that the selected set of cephalofacial variables (head height, horizontal circumference of head, and face height) can, successfully and significantly predict the estimation of body height.

The specific regression equation calculated for the prediction of stature for the Kosovo Albanian population shows high degree of reliability. Using this new formula that was applied to each measured subject; we have derived one new variable, which indicates the predicted estimation of body height. Then, the mean of body height, estimated by regression equation, was compared with the mean of the true body height.

Statistical analysis with the paired t-test has revealed that the predicted estimates of body height are not different from true height; respectively both results are very similar.

The derived regression equation is specific for the given population upon which the regressive equation is based, and cannot be used on other populations of the world, as well as it cannot be expected that the predicted results of body height will be the same with the original results of body height.

The results of this study may be practically very useful for forensic medicine personnel of our country, especially when after war in this region the problems like the thousands of missing persons, many massive graves, as well as problems with identification of the unknown skeletal remains, are very actual.

REXHEPI, A. M. \& BRESTOVCI, B. Predicción de la estatura de acuerdo a tres medidas de la cabeza. Int. J. Morphol., 33(3):1151-1155, 2015.

RESUMEN: La morfometría es un importante método no invasivo para evaluar el tamaño, proporciones y composición del cuerpo humano. Debido a que la predicción es un tema importante en casi todas las ciencias de la vida, el objetivo de esta investigación fue averiguar las variables cefalofaciales que pueden predecir la altura del cuerpo. Se midieron tres variables cefalofaciales y la altura en 288 adultos varones de la población albanesa de Kosovo, de entre 18 a 35 años de edad. Con el uso de procedimientos de análisis regresivo se encontraron las siguientes variables cefalofaciales: altura de la cabeza, circunferencia de la cabeza, altura de la cara. Estas variables pueden predecir significativamente la altura del cuerpo, y de esta manera se obtuvo una ecuación de regresión específica para la estimación de la altura del cuerpo, sobre la base de estas variables cefalofaciales. La predicción de la altura del cuerpo presentó una alta correlación significativa $(0,512)$ con la verdadera altura del cuerpo, estableciendo con la prueba T una similitud significativa entre estas dos variables.

PALABRAS CLAVE: Morfometría; Variables céfalo faciales Estatura; Análisis de regresión.

\section{REFERENCES}

Agnihotri, A. K.; Kachhwaha, S.; Googoolye, K. \& Allock, A. Estimation of stature from cephalo-facial dimensions by regression analysis in Indo-Mauritian population. J. Forensic Leg. Med., 18(4):167-72, 2011.

Asha, K. R. \& Lakshmi Prabha, R. Estimation of stature from cephalic dimensions in Indian population. AnatvK., 5(1):1-5, 2011. Available from: http://www.scopemed.org/ fulltextpdf.php?mno=10636

Auyeung, T. W.; Lee, J. S.; Kwok, T.; Leung, J.; Leung, P. C. \& Woo, J. Estimation of stature by measuring fibula and ulna bone length in 2443 older adults. J. Nutr. Health Aging, 13(10):931-6, 2009.

Coon, C. S. The races of Europe. 2nd ed. New York, Macmillan, 1939. pp.293.

Dhima, A. Gjurmime antropologjike per shqiptaret (Anthropological surveys on the Albanians). Tirana, Akademia e Shkencave e RPS T, 1985. pp.28-9, 106-12, 126-8.

Duyar, I. \& Pelin, C. Body height estimation based on tibia length in different stature groups. Am. J. Phys. Anthropol., 122(1):237, 2003. 
Duyar, I. \& Pelin, C. Estimating body height from ulna length: need of a population-specific formula. Eurasian J. Anthropol., 1(1):11-7, 2010.

Guan, X. \& Zhuang, H. A method of creating 3-D face images from 2-D photos for face recognition. Int. J. Biom., 3(1):4055,2011

Habib, S. R. \& Kamal, N. N. Stature estimation from hand and phalanges lengths of Egyptians. J. Forensic Leg. Med., 17(3):156-60, 2010.

Ilayperuma, I. On the prediction of personal stature from cranial dimensions. Int. J. Morphol., 28(4):1135-40, 2010.

Jantz, L. M. \& Jantz, R. L. Secular change in long bone length and proportion in the United States, 1800-1970. Am. J. Phys. Anthropol., 110(1):57-67, 1999.

Kalia, S.; Shetty, S. K.; Patil, K. \& Mahima, V. G. Stature estimation using odontometry and skull anthropometry. Indian J. Dent Res., 19(2):150-4, 2008.

Krishan, K. \& Kumar, R. Determination of stature from cephalofacial dimensions in a North Indian population. Leg. Med. (Tokyo), 9(3):128-33, 2007.

Krishan, K. Estimation of stature from cephalo-facial anthropometry in north Indian population. Forensic Sci. Int., 181(1-3):52.e1-6, 2008.

Krishan, K.; Kanchan, T. \& DiMaggio, J. A. A study of limb asymmetry and its effect on estimation of stature in forensic case work. Forensic Sci. Int., 200(1-3):181.e1-5, 2010.

Martin, R. \& Saller, K. Lehrbuch der Anthropologie in Systematischer Darstellung. Stuttgart, Fischer Verlag, 1959.

Ornitz, D. M. \& Marie, P. J. FGF signaling pathways in endochondral and intramembranous bone development and human genetic disease. Genes Dev., 16(12):1446-65, 2002.

Ozaslan, A.; Karadayi, B.; Kolusayin, M. O.; Kaya, A. \& Afsin, H. Predictive role of hand and foot dimensions in stature estimation. Rom. J. Leg. Med., 20(1):41-6, 2012.

Patil, K. R. \& Mody, R. N. Determination of sex by discriminant function analysis and stature by regression analysis: a lateral cephalometric study. Forensic Sci. Int., 147(2-3):175-80, 2005.

Pelin, C.; Zagyapan, R.; Yazici, C. \& Kürkcüoglu, A. Body height estimation from head and face dimensions: a different method. J. Forensic Sci., 55(5):1326-30, 2010.

Rao, P. P.; Sowmya, J.; Yoganarasimha, K.; Menezes, R. G.; Kanchan, T. \& Aswinidutt, R. Estimation of stature from cranial sutures in a South Indian male population. Int. J. Legal Med., 123(3):271-6, 2009.
Rexhepi, A. \& Meka, V. Cephalofacial Morphological Characteristics of Albanian Kosova Population. Int. J. Morphol., 26(4):935-40, 2008.

Ryan, I. \& Bidmos, M. A. Skeletal height reconstruction from measurements of the skull in indigenous South Africans. Forensic Sci. Int., 167(1):16-21, 2007.

Stinson, S. \& Frisancho, R. A. Body proportions of highland and lowland Peruvian Quechua children. Hum. Biol., 50(1):57-68, 1978.

Waghmare, V.; Gaikwad, R. \& Herekar, N. Estimation of the stature from the anthropometric measurement of hand length. Internet J. Biol. Anthropol., 4(2), 2011.

\section{Correspondence to: Agron M. Rexhepi Str. "Sali Butka" Nr.31/D 10000 Prishtina KOSOVO}

Email: agronmrexhepi@gmail.com

Received: 24-11-2014

Accepted: 28-07-2015 